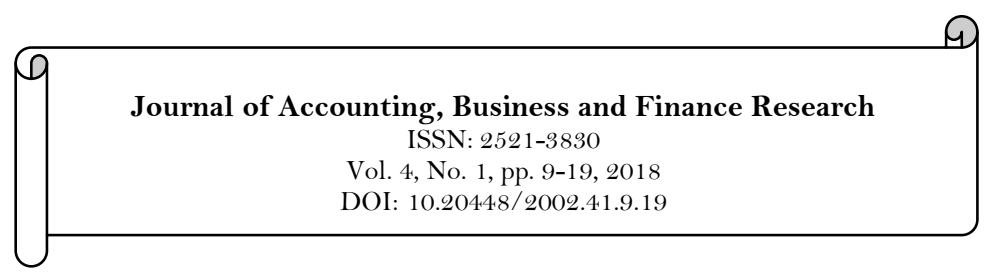

\title{
Cultural Relevance to Sustainability Reporting in Asian and European Banking
}

\author{
Inten Meutia ${ }^{1 *}$ \\ Sari Mustika ${ }^{2}$ \\ Mohamad Adam ${ }^{3}$ \\ ${ }^{1}$ Accounting Dept, Faculty Economy, University Sriwijaya, Indonesia. \\ Email: inten.26@gmail.com \\ ${ }^{2}$ Postgraduate Program, Faculty Economy, University Sriwijaya, Indonesia. \\ ${ }^{3}$ Management Dept, Faculty Economy, University Sriwijaya, Indonesia.
}

\begin{tabular}{|c|c|}
\hline Abstract & \\
\hline $\begin{array}{l}\text { The purpose of this paper is to test whether significant differences in } \\
\text { sustainability reporting exist between banking in Asian and } \\
\text { European. The sample consists of } 65 \text { banks from } 15 \text { countries in } \\
\text { Asian and } 18 \text { countries in European. The division of Asian and } \\
\text { European is derived from the Hofstede cultural dimension. This } \\
\text { study uses GRI financial services sector supplement to measure } \\
\text { sustainability reporting. Non-parametric (Mann-Whitney) tests are } \\
\text { computed to achieve the stated objective. Result reveals that } \\
\text { sustainability reporting in European is higher than in Asian. This } \\
\text { supports the first hypothesis. Differences test results also support } \\
\text { hypothesis that there is a significant differences in sustainability } \\
\text { reporting between the two regions. However, differences test result } \\
\text { per category show that there is no significant differences for the } \\
\text { economic category and there are significant differences for both other } \\
\text { categories, namely social and environmental. The finding suggests } \\
\text { that sustainability reporting is likely to be influenced by national } \\
\text { cultures. With regard to data, Hofstede dimensions were identified } \\
\text { and developed over } 30 \text { years ago and no development over time with } \\
\text { dimensional scores. Rather than comparing two countries, this study } \\
\text { tries to analyze on a broader scale, ie territory. }\end{array}$ & $\begin{array}{l}\text { Keywords: } \\
\text { Sustainability reporting } \\
\text { Hofstede cultural dimension } \\
\text { National cultures } \\
\text { Financial services. } \\
\text { JEL Classification: } \\
\text { M40,G39,Z13. } \\
\text { Licensed: } \\
\text { This work is licensed under a } \\
\text { Creative Commons Attribution } \\
\text { 4.0 License. } \\
\text { Publisher: } \\
\text { Scientific Publishing Institute }\end{array}$ \\
\hline
\end{tabular}

\section{Introduction}

In recent years, sustainability issues have become increasingly important for organizations worldwide (Adams \& Narayanan, 2007) with sustainability reporting having emerged as a key reporting mechanism of accountability organizations. Sustainability reporting is a practice of measuring, disclosing, and accountability to internal and external stakeholders of the organization's performance towards sustainable development goals (Global Reporting Initiative, 2006).

This practice is voluntary reporting that demonstrates the inclusion of social dimensions and environmental concerns in business operations as well as in interaction with stakeholders (Marrewijk \& Werre, 2003). Sustainability reporting can be considered a new trend in corporate reporting that integrates the company's financial, environmental and social performance into a single report (Zwetsloot \& Van Marrewijk, 2004); (Christofi, Christofi, \& Sisaye, 2012); (Hahn \& Kühnen, 2013).

The idea of sustainability has three dimensions derived from the Triple Bottom Line concept introduced by John Elkington in 1994. Sustainability reports are also demanded and expected by investors, customers, employees, government and other stakeholders (Strand, 2014).

Culture has long been recognized as a key characteristic underlying systematic differences in management behavior (Naor, Goldstein, Linderman, \& Schroeder, 2008). Cultural norms and beliefs are dimensions that affect perception, disposition, and human behavior (Kull \& Wacker, 2010).

In terms of culture, accounting researchers have sought to integrate cross-national differences in societal (cultural) values to explain management behaviors and accounting phenomena such as reporting practices, earnings management, social reporting and the environment (Han, Kang, \& Salter, 2010). Since the conceptual 
framework (Gray, 1988) suggests that Hofstede's cultural dimension may influence accounting values (conservatism, transparency, uniformity), the use of state culture in accounting research has gained much attention from researchers (Secord \& Su, 1994), (Hope, 2003), (Doupnik \& Tsakumis, 2004), (Tsakumis, 2007), (Chand, Patel, \& Day, 2008), (Hans, Kang, Salter, \& Yoo, 2010), (Orij, 2010), (Khlif, 2016), (Salter \& Lewis, 2011), (Lee \& Herold, 2016), (Khlif, 2016). Kirkman, Lowe, and Gibson (2006) suggests that Geert Hofstede's cultural classification represents the most influential national cultural framework in business literature and has inspired many empirical studies.

Hofstede's cultural dimensions have also been hypothesized to influence financial reporting policies (Hope, 2003); (Jaggi \& Low, 2000) social and environmental reporting (Orij, 2010); (Khlif, 2016); (Emeni \& Ugbogbo, 2014) and earnings management practices (Riahi \& Omri, 2013); (Doupnik, 2008); (Pacheco \& Wheatley, 2017).

Hoftsede introduces five cultural dimensions consisting of: power distance index, uncertainty avoidance index, individualism vs. collectivism, masculinity vs. feminity, and long term orientation. Based on the index data of each dimension Hofstede there is a tendency that the index of PDI in Asian is higher than in European. The index uncertainty avoidance, individualism, masculinity and long term orientation tend to be higher in European than in Asian (Hofstede, 1980).

The issue of sustainability reporting has become a global issue. This means that differences between countries can also cause differences in reporting as stated by Khlif (2016) national culture may affect corporate reporting policy. The goal here is to detect the cultural aspects of the country that have an identifiable influence on sustainability reporting.

Therefore, this study will examine whether there are significant differences between bank sustainability reports in Asian and European. The idea behind this research is to examine cultural relevance based on Hofstede's cultural dimension on sustainability reporting in both regions.

The rest of the paper is organized as follows. The next section contains an overview of previous research, particularly similar research on the determinants of sustainability reporting and studies that link social or financial accounting with culture. This is followed by a theoretical framework, including previous related literature. The next section contains the development of hypotheses, methods and research results. The final section includes conclusions and limitations.

\section{Literature Review and Hypothesis Development \\ 2.1. Hofstede Theory}

Hofstede's work on the national cultural dimension began in the 1960s. Research conducted for IBM staff in offices around the world.

Hofstede originally identified four dimensions that represent the values of people in the workplace related to the country in which they work. Hofstede refers to the dimension as "difference". The four dimensions are power distance index (PDI), individualism versus collectivism (IDV), masculinity vs feminity (MAS) and uncertainty avoidance index (UAI). The fifth dimension, long term orientation (LTO) was added in 1987 (Hofstede, Hofstede, \& Minkov, 2010).

Hofstede et al. (2010) establishing five dimensions as an index for all countries by linking the demographic, geographical, economic and political aspects of a society. This concept is useful in formulating hypotheses for comparative cross-cultural research.

(1) Power Distance Index / PDI

Power distance measures society's acceptance of differences in power distribution within an organization or institution (Hofstede, 1984). In general, the high power distance indicates the condition of the community is more receptive to what is presented in the report so that the demand for information on an institution tends to be lower, and vice versa (Violita, Syahroza, \& Nasution, 2014). Countries with higher power distance accept that there is a hierarchy between superiors and subordinates (Javidan, House, Dorfman, Hanges, \& Sully de Luque, 2006). Those with a high power distance culture tend to rely on superiors to make decisions. Those with a high power distance culture tend to rely on superiors to make decisions (Lim, 2004). Power distance refers to the level of equality or inequality between people in a country. High power distance scores also imply that power inequality prevails in a country (Khlif, 2016). According to Once and Almagtome (2014) if the level of power distance in a country is high then the level of environmental reporting conducted by the company is low.

(2) Uncertainty Avoidance Index (UAI)

Uncertainty avoidance is the degree to which societies within a culture are in an unstructured, unclear, ambiguous or unpredictable situation in the future (Hofstede, 1984). People who are in a culture of high uncertainty avoidance tend to be emotional. They try to minimize the unusual circumstances. In the event of a change, it will be faced with caution, planning and applying the rules of law and regulations. The high uncertainty avoidance index indicates that the company is concentrating more on things that have more certainty. Communities with high levels of uncertainty will reduce the impact of uncertainty with technology and regulation. Managers in conditions with higher uncertainty avoidance rates, will further avoid risk (Zhang, Zhang, \& Zhang, 2015). In contrast to the low uncertainty avoidance index 
where people accept and feel comfortable in unstructured situations or changing environments. They tend to have some rules in their activities, and tend to be more pragmatic and more tolerant of change. Cultures with high uncertainty avoidance in a country will affect the company's management to make reportings with high levels of information (Priyastiwi, 2016). With regard to the reporting of sustainability reporting, Hofstede points out that in a society with high levels of uncertainty avoidance, this will be neutralized with the rules of law and regulations. In line with the European region has improved instrument sustainability reporting compared to Asian which has a low uncertainty avoidance index.

(3) Individualism versus collectivism (IDV)

Individualism vs. collectivism is how people define themselves and their relationships with others. Culture of individualism encourages its members to be independent, emphasizing responsibility and personal rights. While Collectivism is a relatively strict social function tendency in which each individual identifies as a group with loyalty no doubt. According to Hofstede (1980) the majority of people in the world live in collectivist societies, "in which group interest applies to individual interests". Conversely, a small percentage lives in an individualist society. In this society individual interests win over group interests. Individualism refers to independence and emotional independence. Jaggi and Low (2000) suggest that managers in more individual societies tend to disclose more because people in more individualistic societies tend to be more competitive and transparancy.

(4) Maskulinity vs Feminity (MAS)

The dimension of masculinity is related to differences in gender values in society, the different distribution of emotional roles between men and women. The dimension of masculinity in national culture is a form of social behavior that prioritizes competition, power, ambition, assertiveness, tend to seek wealth and other possessions and cultures where society is generally more competitive. While feminity prefers cooperation, humility, concern, and a more consensus-oriented society (collective agreement) (Hofstede et al., 2010). In a very masculine society, managers place great importance on operating performance because good corporate performance gives them more social rewards and personal rewards (Zhang et al., 2015). Gray (1988) argues that masculinity tends to be consistent with transparency. This is because masculinity shows a resolute and oriented society of success that can show a tendency for more publicity. With regard to sustainability reporting, corporate management in countries with high masculinity indexes tends to perform better reporting of sustainability reporting.

(5) Long Term vs Short Term Orientation (LTO)

Long-term and short-term orientation is the extent of the community's ability to reflect on its potential to analyze a problem. Long-term oriented communities address problems in a flexible and focused way on the future. People in short-term orientations tend to overcome the problem as a whole or partial. The high long-term orientation index of a country implies that the company wants to establish good relationships with stakeholders as a way of maintaining strong ties or cooperation with stakeholders until the future (Khlif, 2016). According to Once and Almagtome (2014) the higher long-term orientation index in a country will lead to higher corporate reporting.

According to Hofstede et al. (2010) the index of power distance (PDI) in Asian countries is higher than in most European countries. If the index of power distance is low then the dependence on the subordinate to the leadership is limited, there is an interdependence relationship between superiors and subordinates and the emotional distance between superiors and subordinates becomes low, and vice versa.

Meanwhile, the uncertainty avoidance index (UAI) tends to be higher in countries in Eastern and Central European, whereas in Asian region has medium to low level, except in Korea which has high UAI. Individualism tends to apply in Western or developed countries, while collectivism prevails in less developed countries and Eastern countries.

With regard to the Index of masculinity, the German state and some Latin countries such as Italy have a high index of masculinity, Western countries that speak high enough English. While countries in Asian tend to have a low index of masculinity. The long-term orientation index tends to be high in Korea and European countries, while short-term orientation is found in Finland and other Asian countries with medium to low levels.

Hofstede (1980) approach has been widely used in accounting studies, one of the most phenomenal is research conducted by Gray (1983). Gray (1983) using models (Hofstede, 1980) on social values and institutional structures by extending them to financial reporting areas. Gray (1983) hypothesize the existence of an accounting sub-culture that states: the value system or behavior of accountants is very likely to be influenced, related and derived from social values.

Gray (1988) points out that culture is an important element in understanding how social systems change because cultures influence both the norms and values of such systems and group behavior in their interactions within and across systems. He states that the term 'culture' is reserved as a whole, for the state, while the term " subculture 'is used for organizational, professional, or family level. While acknowledging that the degree of cultural integration varies throughout society, Gray (1988) explores the relationship between culture and international accounting systems at the subculture level. Given that cultural values penetrate a country's 
social system, it presents a theoretical argument for the relationship between national culture and the pattern of accounting systems across the country.

\subsection{Priors Research}

The relationship of national culture (as measured by Masculinity vs. Femininity, Long vs. Short-Term Orientation, Individualism vs. collectivism, power distance, and uncertainty avoidance) with sustainability reportings (financial, environmental and social) has been studied by the following researchers:

Tsakumis (2007) in his studies of companies in Greece and the United States by adopting Hofstede and Gray Framework examined the effect of cultural factors on the application of financial reporting standards. His findings show that accountants in Greece are more covert in expressing the existence of contingent liabilities and assets when compared to accountants in the US. There was also found a strong association between the Gray hypothesis hypothesis and the practice of accounting reporting. Nevertheless, there are no significant differences with respect to professional judgment and recognition of contingent and asset liabilities between the two countries.

Chand et al. (2008) conducted studies on companies in Fiji and Australia based on Hofstede's cultural values to determine the effects of non-cultural and cultural factors on the professional assessment of accountants. The results show that accountants in Fiji are more conservative when compared to accountants in Australia. Furthermore, the results show that the national culture has a significant impact on the way the professional assessment of the accountant.

Akman (2011) in his study of six countries using Hofstede's cultural dimension to investigate whether differences in financial reporting due to culture have diminished after the adoption of IFRS. The results show that the cultural dimensions of individualism, power distance, uncertainty avoidance and masculinity significantly influence the level of corporate finance reporting of the sample. The use of IFRS does not eliminate the cultural impact on financial reportings.

The above studies use individualism / collectivism; power distance; avoidance of uncertainty; masculinity / femininity and / short / long orientation as cultural indicators.

Subsequently Salter and Lewis (2011) in a study of 15 countries using the Gray framework and Hofstede cultural dimensions using data for seven years to determine the relationship between one of Gray's accounting values (and conservatism) and Hofstede's cultural size. The results of the evaluation show that the value of individualism culture is positively and significantly correlated with the differences in the practice of measuring income between countries.

Adelopo, Ceo Moure, and Obalola (2013) in their study used Hofstede's two-dimensional culture to examine the impact of legal origin and culture on Corporate Social Responsibility on major banks in fourteen Western European countries.

The findings show that the origin and culture of state law affect the reporting behavior of banks. Banks in civil law countries make more social reportings about workers and shareholders than banks in the Common law. In addition, banks in the culture of high uncertainty avoidance make more social reporting of banks in the culture of avoidance of low uncertainty. However, no relationship is found between the reporting of corporate social responsibility and the cultural dimension of individualism / collectivism. The study supports institutional and cross-country studies.

Emeni and Ugbogbo (2014) examining different cultural dimensions (Hofstede's power distance and individualism / collectivism) and its impact on accounting reporting practices in Nigeria with 278 sample companies. It was found that collectivism and the dimensions of power distance positively influence the practice of accounting reporting.

Collectivism was found to have a significant effect, while individualism was found to be negatively and insignificantly associated with the practice of accounting reporting in Nigeria.

The banking sector is the focus of this research because the issue of sustainable financing (financial sustainability) is an issue that attracts the world's attention today. According to research Chowdhury, Datta, and Mohajan (2013) in the last two decades of the $20^{\text {th }}$ century green finance has become an interesting issue in finance and banking.

In addition, the Commission action plan on sustainable finance in European has developed a comprehensive strategy for linking finance with sustainability as a follow-up to the establishment of the High Level Expert Group on Sustainable Finance in December 2016. For this reason, this study will conduct analysis on both groups of countries, European and Asian (as a group of developing countries) to identify whether there are differences in sustainability reporting by banks in both groups of countries.

Research conducted by Kanagaretnam, Lim, and Lobo (2014) is a study that also examines the influence of culture on accounting practices in banking, especially risk taking.

Using samples of international banks and country-level indices for individualism and uncertainty avoidance as a proxy for national culture, they study how differences in cross-country cultures affect accounting conservatism and risk taking of banks. Consistent with expectations, cross-country analysis shows that negative (positive) individualism is related to conservatism (risk-taking) and avoidance of uncertainty 
positively (negatively) related to conservatism (risk-taking). It was also found that a culture that encouraged higher risk taking experienced more bank failures and bank problems during the recent financial crisis.

This research will contribute to research on cultural relevance to sustainability reporting. With regard to sustainability measurement, this study uses GRI sector supplement for financial services. Based on the best knowledge of the researchers this instrument is different from previous studies that mostly use general GRI guidelines.

Another update of this study is in the context of comparing two regions of Asian and European which, according to Hofstede et al. (2010) European countries are countries that tend to have low power distance index, high uncertainty avoidance, high individualism, high masculinity and long-term orientation is also relatively high. The Asian group of countries are countries that tend to have high power distance index, low uncertainty, low masculinity and low long-term orientation. Based on what was previously described, this research formulates the hypothesis:

H1: Sustainability reporting index for banks in European is higher than in Asian.

H2: There are differences sustainability reporting index in each category (economy, environment, social) between banks in Asian and European.

H2: There are differences in sustainability reporting index between banks in Asian and European.

\section{Research Method}

\subsection{Population, Sample and Data}

The population of this study are banks in Asian and European that publish GRI reports. There are 56 banks in Asian that publish GRI reports, and 81 in European. Of 56 banks in Asian, 31 banks make reports not in English. While from 81 banks in European, the sample is only 34, because 47 banks do not provide reports in English. So the total sample becomes as much as 65 banks.

The analysis focuses on banking in the Asian and European region which comes from 33 countries ie 15 Asian countries and 18 from European. The data obtained from the annual report of each bank with the focus of the study period is 2016 .

Table-1. Countries of Research Sample.

\begin{tabular}{l|l|l|l|l|l}
\multicolumn{7}{c}{ Table-1. Countries of Research Sample. } & Total & No & European & Total \\
\hline No & Asian & 3 & 1 & Belgium & 1 \\
\hline 1 & Bangladesh & 6 & 2 & Finland & 2 \\
\hline 2 & Indonesia & 1 & 3 & France & 4 \\
\hline 3 & Cambodia & 4 & 4 & Greece & 1 \\
\hline 4 & India & 1 & 5 & Germany & 1 \\
\hline 5 & Israel & 1 & 6 & Great Britain & 1 \\
\hline 6 & Jordan & 1 & 7 & Italy & 3 \\
\hline 7 & Korea Republic & 2 & 8 & Luxembourg & 1 \\
\hline 8 & Malaysia & 4 & 9 & Netherlands & 6 \\
\hline 9 & Philippines & 1 & 10 & Portugal & 1 \\
\hline 10 & Qatar & 1 & 11 & Poland & 1 \\
\hline 11 & Singapore & 1 & 12 & Russian & 1 \\
\hline 12 & Saudi Arabia & 3 & 13 & Slovakia & 1 \\
\hline 13 & Thailand & 1 & 14 & Spain & 1 \\
\hline 14 & UAE & 1 & 15 & Sweden & 4 \\
\hline 15 & Vietnam & & 16 & Switzerland Fr & 2 \\
\hline & & & 17 & Switzerland Gr & 1 \\
\hline & & & 18 & Turkey & 1 \\
\hline & & 31 & & Total & 34 \\
\hline & Total & & &
\end{tabular}


Table-2. Categories of Reporting under the Financial Service Sector Supplement.

\begin{tabular}{|c|c|c|c|c|}
\hline No & Categories & Sub categories & Item & Reporting \\
\hline 1 & Economy & $\begin{array}{l}\text { Economy } \\
\text { Performance } \\
\end{array}$ & & G4-DMA; G4-EC1 \\
\hline \multirow[t]{2}{*}{2} & \multirow{2}{*}{ Environment } & Emission & & $\begin{array}{l}\text { G4-EN15; G4-EN } 16 \\
\text { G4-EN17 }\end{array}$ \\
\hline & & Waste & & G4-EN23 \\
\hline \multirow{7}{*}{3} & \multirow{7}{*}{ Social } & $\begin{array}{l}\text { Occupational heatlh } \\
\text { and Safety }\end{array}$ & $\begin{array}{l}\text { Worker health } \\
\text { and safety }\end{array}$ & $\begin{array}{l}\text { G4-LA5; G4-LA6; G4-LA7; } \\
\text { G4-LA8 }\end{array}$ \\
\hline & & Human Right & Investment & G4-HR 1 \\
\hline & & Community & $\begin{array}{l}\text { Local } \\
\text { Communities }\end{array}$ & FS13; FS14 \\
\hline & & \multirow{4}{*}{$\begin{array}{l}\text { Product } \\
\text { responsibility }\end{array}$} & $\begin{array}{l}\text { Portofolio } \\
\text { Product }\end{array}$ & $\begin{array}{l}\text { FS1; FS2; FS3; FS4 FS5;FS6; } \\
\text { FS7; FS8 }\end{array}$ \\
\hline & & & Audit & FS9 \\
\hline & & & $\begin{array}{l}\text { Active } \\
\text { Ownership }\end{array}$ & FS10; FS11; FS12 \\
\hline & & & $\begin{array}{l}\text { Labelling } \\
\text { product and } \\
\text { Service }\end{array}$ & FS $15 ; \mathrm{FS} 16$ \\
\hline
\end{tabular}

This study uses the GRI financial services supplement sector as a measure of sustainability reporting index. The use of this instrument is expected to measure the sustainability reporting index that should be done by banks. GRI Financial Service Sector Supplement consists of 27 items in 3 categories namely economic, environmental and social. Social category consists of 4 sub-categories, namely employment practices and comfort work, human rights, community and responsibility for the product.

This study uses content analysis which is a method of codifying text (or content) of a piece of writing or category depending on the selected criterion (Krippendorf, 1989). Content analysis are widely used in corporate social reporting research such as (Aribi \& Gao, 2010), (Mallin, Farag, \& Ow-Yong, 2014), (Beattie, 2014), (Qiu, Shaukat, \& Tharyan, 2016), (Yook, Song, Patten, \& Kim, 2017).

The Sustainability Reporting Index is calculated as follows:

$$
\text { SRDI }=\frac{\text { Total item Disclose }}{\text { Total item Expected Disclose }} \times 100
$$

Reliability and validity in content analysis refers to the measurement procedure, which ensures to give the same results on repetitive traces. In other words, reliability and validity are determined to ensure that different researchers will encode the text in the same way and therefore reduce the likelihood of inaccuracy and bias. A number of steps are taken to ensure reliability.

The Cronbach coefficient has been used for internal consistency sustainability reporting checks. The Cronbach coefficient a, is an internal consistency measure that uses repeatable measurements to assess the extent to which correlations between measurements are attenuated to random error (Botosan, 1997). For each category, the value of the Cronbach a coefficient is 0.624 , which is sufficient at an acceptable level.

\section{Findings and Discussion}

This section presents statistics descriptive of the mean values of power distance index, uncertainty avoidance index, individualism vs collectivism index, masculinity vs feminity index, and long term orientation vs short term index in the Asian and European region Table 3.

\begin{tabular}{|c|c|c|c|c|c|}
\hline \multirow{2}{*}{ Region } & PDI & UAI & IDV & MAS & LTO \\
\hline & Index & Index & Index & Index & Index \\
\hline Asian & \multirow[b]{2}{*}{73,6} & \multirow[b]{2}{*}{53,2} & \multirow[b]{2}{*}{29,6} & \multirow[b]{2}{*}{48,73} & \multirow[b]{2}{*}{48,53} \\
\hline Mean & & & & & \\
\hline European & \multirow[b]{2}{*}{55,78} & \multirow[b]{2}{*}{73,17} & \multirow[b]{2}{*}{60,17} & \multirow[b]{2}{*}{50,83} & \multirow[b]{2}{*}{59,55} \\
\hline Mean & & & & & \\
\hline
\end{tabular}


The result in Table 3 show that mean of power distance index in Asian is higher than in European. While the mean of uncertainty avoidance index, individualism vs. colectivism, masculinity vs. feminity and long term orientation are higher in the European region than in the Asian region.

Table-4. Descriptive Statistics.

\begin{tabular}{l|l|l|l|l|l}
\hline & N & Mean & Std. Deviation & Minimum & Maximum \\
\hline $\begin{array}{l}\text { Sustainability } \\
\text { Reporting Index }\end{array}$ & 65 & 42,5646 & 17,81247 & 11,11 & 96,30 \\
\hline Country & 65 & 1,52 &, 503 & 1 & 2 \\
\hline
\end{tabular}

Data in Table 4 shows that sustainability reporting index has mean of 42.5646, minimum value 11.11 maximum values 96.30 with standard deviation 17.81247. The highest sustainability-reporting index, 96.3 is from Italy, while the lowest is from Philippines (11.11). This data indirectly shows that sustainability reporting index in European countries is higher than in Asian countries.

A summary of the sustainability reporting index by banks in Asian and European is presented in Table 5 . Overall the index of sustainability reporting is higher in banks in European than in Asia. The mean of sustainability reporting index in banks in European is 49.7826 while in Asian 34.6481. This finding supports the first hypothesis that the average sustainability reporting index in banks in European is higher than in Asian.

Table-5. Descriptive Sustainability Reporting Index.

\begin{tabular}{l|l|ll}
\hline & Asian & European \\
\hline Mean & 34.6481 & 49,7826 & \multicolumn{2}{|c}{48,1500} \\
\hline Median & 29.6300 & \multicolumn{2}{l}{} \\
\hline Maximum & 77.78 & 96,30 & \\
\hline Minimum & 11.11 & 22,22 & \\
\hline St. Dev & 15.84552 & 16,56901 \\
\hline
\end{tabular}

Countries in European tend to have high levels of uncertainty avoidance. Zhang et al. (2015) states to reduce the impact of uncertainty avoidance then they will use more technology and regulations. This is indicated in the presence directive on the disclosure of non-financial and diversity information (Directive 2014/95/EU) issued by European Union.

Further followed by rules issued by various countries in European, such as Sustainability and Diversity Improvement Act 257/ME (Austria), Legislative Decree 30 December 2016, n. 254 (Italy), Decree Disclosure of Non-financial Information PbEU, 2014, L330 and Decree Disclosure Diversity Policy PbEU, 2014, L330 (Netherland), Corporate Reporting on Sustainability and Diversity Policy CU2 (Sweden) and many more. The existence of these rules encourages companies in European to publish sustainability reports

Table 6 show the mean, median, minimum and maximum values of each category of sustainability reporting reporting ie economic, social and environmental in each region.

Table-6. Descriptive Sustainability Index per Category and Regions.

\begin{tabular}{|c|c|c|c|c|}
\hline No & Category & & Asian & European \\
\hline \multirow{5}{*}{1} & \multirow{5}{*}{ Economy } & Mean & 88,7097 & 83,8235 \\
\hline & & Median & 100 & 100 \\
\hline & & Maximum & 100 & 100 \\
\hline & & Minimum & 50 & 50 \\
\hline & & St. Dev & 21,25119 & 23,7429 \\
\hline \multirow{5}{*}{2} & \multirow{5}{*}{ Environment } & Mean & 52,4194 & 76,4706 \\
\hline & & Median & 50 & 75 \\
\hline & & Maximum & 100 & 100 \\
\hline & & Minimum & $\mathrm{O}$ & 25 \\
\hline & & St. Dev & 37,27982 & 22,14037 \\
\hline \multirow{5}{*}{3} & \multirow{5}{*}{ Social } & Mean & 26,2965 & 41,1774 \\
\hline & & Median & 23,81 & 38,1 \\
\hline & & Maximum & 76,19 & 95,24 \\
\hline & & Minimum & 4,76 & $\mathrm{O}$ \\
\hline & & St. Dev & 19,70791 & 21,16272 \\
\hline
\end{tabular}

The data in Table 6 illustrate for the economic category banks in Asian has a higher sustainability reporting index than in European. But in the environmental and social categories, banks ini European has a higher sustainability reporting index than Asian. This show that banks in Asian pay more attention to the reporting of sustainability related to economic aspects than environmental and social aspects. While banks in 
European countries are already at a more advanced stage with more attention to social and environmental issues. This is in accordance with what is conveyed by Christofi et al. (2012) and in harmony with the research result (Emeni \& Ugbogbo, 2014). This finding also supports what Once and Almagtome (2014) that if the level of power distance in a country is high then the level of environmental reporting conducted by the company is low.

Furthermore the normality test performed on the data, indicating that the data is not normally distributed. Therefore, the Mann-Whitney $U$ test is used to examine the differences in sustainability reporting index both in whole and in each category, economic, environmental and social. Mann-Whitney U test results can be seen below in the Table 7 .

Table-7. Ranks Mann-Whitney Test by Sustainability Category.

\begin{tabular}{|c|c|c|c|c|}
\hline \multicolumn{5}{|l|}{ Ranks } \\
\hline & Country & $\mathrm{N}$ & Mean Rank & Sum of Ranks \\
\hline \multirow{3}{*}{ Economy } & Asian & 31 & 34,66 & 1074,5 \\
\hline & European & 34 & 31,49 & 1070,5 \\
\hline & Total & 65 & & \\
\hline \multirow{3}{*}{ Environment } & Asian & 31 & 26,77 & 830 \\
\hline & European & 34 & 38,68 & 1315 \\
\hline & Total & 65 & & \\
\hline \multirow{3}{*}{ Social } & Asian & 31 & 25,24 & 782,5 \\
\hline & European & 34 & 40,07 & 1362,5 \\
\hline & Total & 65 & & \\
\hline
\end{tabular}

Table 7 illustrates the mean rank for each category of banking sustainability reports in Asian and European. Table 7 shows that banks from Asian countries have higher indexes for economic categories compared with banks in European. As for social and environmental categories, banks from European countries have higher indexes than Asian banks.

Table-8. Mann Whitney U Test P Value.

\begin{tabular}{l|l|l|l}
\hline & Economy & \multicolumn{1}{c}{ Environment } & Social \\
\hline Mann-Whitney U & 475,500 & 334,000 & 286,500 \\
\hline Wilcoxon W & 1070,500 & 830,000 & 782,500 \\
\hline Z &,- 873 & $-2,638$ & $-3,178$ \\
\hline Asymp. Sig. (2-tailed) &, 383 &, 008 &, 001 \\
\hline a. Grouping Variable: Country.
\end{tabular}

Mann-Whitney $\mathrm{U}$ test results in Table 8 shows that there is a significant differences mean rank sustainability reporting index for environmental and social categories in both region, Asian and European. This is evidenced by the value of significance ( $p$ value) $0.008<0.05$ and $0.001<0.05$. While for the economic category there is no significant differences between the two countries $(p>0.05)$.

The analysis to examine the differences in sustainability reporting index as a whole is shown in Table 9 and 10 .

Table-9. Ranks Mann-Whitney Test.

\begin{tabular}{l|l|l|l|l}
\hline \multicolumn{5}{c}{ Table-9. Ranks Mann-Whitney } \\
\hline & Country & N & Mean Rank & Sum of Ranks \\
\hline \multirow{3}{*}{ Sustainability Reporting Index } & Asian & 31 & 23,73 & 735,50 \\
\cline { 2 - 6 } & European & 34 & 41,46 & 1409,50 \\
\cline { 2 - 6 } & Total & 65 & & \\
\hline
\end{tabular}

Table 9 shows the mean rank sustainability-reporting index in each country. The mean rank in European is higher (41.46) than the mean rank in Asian (23.73). To verify whether this mean rank difference is statistically significant can be seen in Table 10 .

\begin{tabular}{l|l}
\multicolumn{2}{c}{ Table-10. Mann Whitney U Test P Value. } \\
\hline \multicolumn{2}{|c}{ Test Statistics $^{\mathbf{a}}$} \\
\hline Mann-Whitney U & Sustainability Reporting \\
\hline Wilcoxon W & 239,500 \\
\hline Z & 735,500 \\
\hline Asymp. Sig. (2-tailed) & $-3,789$ \\
\hline a. Grouping Variable: Country. &, 000 \\
\hline
\end{tabular}


Table 10 shows a $\mathrm{U}$ value of 239.5 and a $\mathrm{W}$ value of 735.5. When converted to a value of $\mathrm{Z}$ the magnitude is -3.789. The value of Sig or P Value is $0.00<0.05$. This means that there is a meaningful difference between the two groups or which means the third hypothesis is accepted.

This means that hypothesis 3 states that there is a difference in the index of sustainability reporting between the two areas accepted.

This finding supports the conceptual framework proposed by Khlif (2016) that national culture can play an important role in shaping the behavior and management orientation in relation to resource allocation and company reporting policies, including sustainability reporting.

In this case, Armstrong, Wayne, and Joseph (2010) says that accounting does not operate in a vacuum: it is the 'product of its environment'. Thus, culture is an important factor in the environment and thus the difference in cultural values can have a significant impact on accounting practices.

\section{Conclusion}

This study provides an explanation of the cultural relevance of sustainability reporting. The relevance described between sustainability reporting and national culture, for most hypotheses, is consistent with that portrayed by Hofstede's theory.

Confirmation of the first hypothesis states that the reporting of banking sustainability in European is higher than in Asian is proven. Although tests on the second hypothesis show that this is not the case in every reporting category. For economic category, Asian is higher than European although this is not significant. Confirmation of the second hypothesis also proves that for the environmental and social categories there are significant differences between the two regions.

With regard to the third hypothesis, it is predicted and confirmed that culture in a country has significant relevance to the sustainability reporting conducted by banks. For banks in countries with cultural characteristics: low power distance index, high uncertainty avoidance, high masculinity, high individualism and long term orientation are likely to make high sustainability reporting, and vice versa. This clearly proves Hofstede's theory.

\section{Research Limitations and Suggestion for Future Research}

Limitations relate to the data and methods applied. With regard to data, Hofstede dimensions were identified and developed over 30 years ago and no development over time with dimensional scores. It can be assumed that developing countries specifically in Asian may have undergone changes in the national cultural dimension.

As stated by Orij (2010) that Hofstede's cultural dimensions scores may experience some changes especially in developing countries where the state of development has witnessed significant changes compared to 30 years ago. Another limitation is the number of samples that may cause data to be abnormal because many published sustainability reports do not use English. To overcome the limitations of samples, further research can expand the research by expanding the research area such as involving banks from countries other than Asian and European.

\section{References}

Adams, C., \& Narayanan, V. (2007). The standardization of sustainability reporting. In: Unermann, J., Bebbington, J. and O’Dwyer, B (Eds.). Sustainability Accounting and Accountability (pp. 70-85). London: Routledge.

Adelopo, I., Ceo Moure, R., \& Obalola, M. (2013). On the effects of legal and cultural institutions on corporate social disclosures by banks (No. 87). Leicester.

Akman, N. H. (2011). The effect of IFRS adoption on financial disclosure: does culture still play a role? American International Journal of Contemporary Research, 1(1), 6-17.

Aribi, Z. A., \& Gao, S. (2010). Corporate social responsibility disclosure. Journal of Financial Reporting and Accounting, 8(2), 72-91. Available at: https://doi.org/10.1108/19852511011088352.

Armstrong, C. S., Wayne, R. G., \& Joseph, P. W. (2010). The role of information and financial reporting in corporate governance and debt contracting. Journal of Accounting and Economics, 5(2-3), 179-234. Available at: http://dx.doi.org/10.1016/j.jacceco.2010.10.001.

Beattie, V. (2014). Accounting narratives and the narrative turn in accounting research: Issues, theory, methodology, methods and a research framework. British Accounting Review, 46(2), 111-134. Available at: https://doi.org/10.1016/j.bar.2014.05.001.

Chand, P., Patel, C., \& Day, R. (2008). Factors causing differences in the financial reporting practices in selected south pacific countries Oin the post-convergence period. Asian Academy of Management Journal, 13(2), 111-129.

Chowdhury, T., Datta, R., \& Mohajan, H. (2013). Green finance in essential for economic development and sustainability. International Journal of Research in Commerce, Economics \& Management, 3(10), 1-6.

Christofi, A., Christofi, P., \& Sisaye, S. (2012). Corporate sustainability: Historical development and reporting practices. Management Research Review, 35(2), 157-172. Available at: https://doi.org/10.1108/01409171211195170.

Doupnik, T. S. (2008). Influence of culture on earnings management: A note. Abacus, 44(3), 317-340. Available at: https://doi.org/10.1111/j.1467-6281.2008.00265.x.

Doupnik, T. S., \& Tsakumis, G. T. (2004). A critical review of tests of Gray's theory of cultural relevance and suggestions for future research. Journal of Accounting Literature, 23, 1-48. 
Emeni, F. K., \& Ugbogbo, S. N. (2014). Accounting frameworks and cross-cultural effects on accounting disclosure practices in Nigeria. Covenant Journal of Business and Social Sciences, 6(2), 48-69.

Global Reporting Initiative. (2006). Sustainability reporting guidelines.

Gray, S. J. (1983). Towards a theory of cultural influence on the development of accounting systems internationally. Abacus, 24(I), 1-15.

Gray, S. J. (1988). Towards a theory of cultural influence on the development of accounting systems internationally. Abacus, 24(I), 1-15.

GRI. (2014). G4 sustainability reporting guidelines (pp. 1-97): GRI.

Hahn, R., \& Kühnen, M. (2013). Determinants of sustainability reporting: A review of results, trends, theory, and opportunities in an expanding field of research. Journal of Cleaner Production, 59, 5-21. Available at: https://doi.org/10.1016/j.jclepro.2013.07.005.

Han, S., Kang, T., \& Salter, S. (2010). A cross-country study on the effects of national culture on earnings management. International Business Studies, 41(1), 123-141.

Hans, S., Kang, T., Salter, S., \& Yoo, Y. K. (2010). A cross-country study on the effects of national culture on earnings management. Journal of International Business Studies, 41(1), 123-141. Available at: https://doi.org/10.1057/jibs.2008.78.

Hofstede, G. (1980). Culture's consequences: International differences in work-related values: Sage. Beverly Hills: Sage Publications.

Hofstede, G. (1984). The cultural relativity of the quality of life concept. Academy of Management Revierw, 9(3), 389-398.

Hofstede, G., Hofstede, G. J., \& Minkov, M. (2010). Cultures and organizations software of the mind. Cultures and Organizations (3rd ed.).

Hope, O. K. (2003). Firm-level disclosures and the relative roles of culture and legal origin. Journal of International Financial Management and Accounting, 14(3), 218-248. Available at: https://doi.org/10.1111/1467-646X.00097.

Jaggi, B., \& Low, P. Y. (2000). Impact of culture, market forces, and legal system on financial disclosures. The International Journal of Accounting, 35(4), 495-519. Available at: https://doi.org/10.1016/So020-7063(00)00076-5.

Javidan, M., House, R. J., Dorfman, P. W., Hanges, P. J., \& Sully de Luque, M. (2006). Conceptualizing and measuring cultures and their consequences: A comparative review of GLOBE's and Hofstede's approaches. Journal of International Business Studies, 37(6), 897-914. Available at: https://doi.org/10.1057/palgrave.jibs.8400234.

Kanagaretnam, K., Lim, C. Y., \& Lobo, G. J. (2014). Effects of national culture on earnings management in banks. The Accounting Review, 89, 1115-1149.

Khlif, H. (2016). Hofstede's cultural dimensions in accounting research: A review. Meditari Accountancy Research, 24(4), 545573. Available at: https://doi.org/http;//dx.doi.org/10.1108/MEDAR-02-2016-0041.

Kirkman, B. L., Lowe, K. B., \& Gibson, C. B. (2006). A quarter century of culture's consequences: A review of empirical research incorporating Hofstede's cultural values framework. Journal of International Business Studies, 37(3), 285320.

Krippendorf, K. (1989). Content analysis. Content Analysis, 1, 403-407. Available at: https://doi.org/10.1002/9781118541555.wbiepc065.

Kull, T. J., \& Wacker, J. G. (2010). Quality management effectiveness in Asia: The influence of culture. Journal of Operations Management, 28(3), 223-239. Available at: https://doi.org/10.1016/j.jom.2009.11.003.

Lee, K.-H., \& Herold, D. M. (2016). Cultural relevance in corporate sustainability management: A comparison between Korea and Japan. Asian Journal of Sustainability and Social Responsibility, 1(1), 1-21. Available at: https://doi.org/10.1186/s41180-016-0003-2.

Mallin, C., Farag, H., \& Ow-Yong, K. (2014). Corporate social responsibility and financial performance in Islamic banks. Journal of Economic Behavior \& Organization, 103(March 2013), S21-S38. Available at: https://doi.org/10.1016/j.jebo.2014.03.001.

Marrewijk, M., \& Werre, M. (2003). Multiple levels of corporate sustainability. Journal of Business Ethics, 44(2-3), $107-119$. Available at: https://doi.org/10.1023/A:1023383229086

Naor, M., Goldstein, S. M., Linderman, K. W., \& Schroeder, R. G. (2008). The role of culture as driver of quality management and performance: Infrastructure versus core quality practices. Decision Sciences, 39(4), 671-702. Available at: https://doi.org/10.1111/j.1540-5915.2008.00208.x.

Once, S., \& Almagtome, A. (2014). The relationship between hofstede's national culture values and corporate environmental disclosure: An international perspective. Research Journal of Business and Management, 1(3), 279304.

Orij, R. (2010). Corporate social disclosures in the context of national cultures and stakeholder theory. Accounting, Auditing $\left\{\Xi^{3}\right\}$ Accountability Journal, 23(7, SI), 868-889. Available at: https://doi.org/10.1108/09513571011080162.

Pacheco, P. A. A., \& Wheatley, C. (2017). The influence of culture on real earnings management. International Journal of Emerging Markets, 12(1), 38-57. Available at: https://doi.org/10.1108/IJoEM-12-2014-0218.

Priyastiwi. (2016). The influence of culture on accounting, auditing and international accounting practices. Journal of Management Research, 3(1), 78-95.

Qiu, Y., Shaukat, A., \& Tharyan, R. (2016). Environmental and social disclosures: Link with corporate financial performance. British Accounting Review, 48(1), 102-116. Available at: https://doi.org/10.1016/j.bar.2014.10.007.

Riahi, R., \& Omri, A. (2013). Cultural relativism in earnings management. International Journal Management Business Research, 3(3), 281-295.

Salter, S. B., \& Lewis, P. A. (2011). Shades of Gray: An empirical examination of Gray's model of culture and income measurement practices using 20-F data. Advances in Accounting, 27(1), 132-142. Available at: https://doi.org/10.1016/j.adiac.2010.08.008.

Secord, P., \& Su, X. (1994). An empirical analysis of culture and accounting models in Asia. Asian Review of Accounting, 2(1), 3-21. Available at: https://doi.org/10.1108/eb060643. 
Strand, R. (2014). Strategic leadership of corporate sustainability. Journal of Business Ethics, 123(4), 687-706. Available at: https://doi.org/10.1007/s10551-013-2017-3.

Tsakumis, G. T. (2007). The influence of culture on accountants' application of financial reporting rules. Abacus, 43(1), 2748. Available at: https://doi.org/10.1111/j.1467-6281.2007.00216.x.

Violita, E. S., Syahroza, A., \& Nasution, M. E. (2014). The role of cultural institutional mediation on the relationship of cultural values and the disclosure of Islamic values. Indonesian Islamic Accounting and Finance Journal, 11(2), 200221.

Yook, K.-H., Song, H., Patten, D. M., \& Kim, I.-W. (2017). The disclosure of environmental conservation costs and its relation to eco-efficiency. Sustainability Accounting, Management and Policy Journal, 8(1), 20-42. Available at: https://doi.org/10.1108/SAMPJ-07-2016-0039.

Zhang, M., Zhang, W., \& Zhang, S. (2015). National culture and firm investment efficiency: International evidence. AsiaPacific Journal of Accounting and Economics, 23(1), 1-21. Available at: https://doi.org/10.1080/16081625.2015.1027714.

Zwetsloot, G. I. J. M., \& Van Marrewijk, M. N. A. (2004). From quality to sustainability. Journal of Business Ethics, 55(2), 79-82. Available at: https://doi.org/10.1007/s 10551-004-1893-y. 